University of Nebraska - Lincoln

DigitalCommons@University of Nebraska - Lincoln

\title{
Degradation and Biological Efficacy of Chlorpyrifos-Methyl on Wheat Stored at Five Temperatures and Three Moisture Contents
}

Frank H. Arthur

USDA-ARS, frank.arthur@ars.usda.gov

James E. Throne

USDA-ARS, Manhattan, KS, james.throne@ars.usda.gov

Richard A. Simonaitis

USDA-ARS

Follow this and additional works at: https://digitalcommons.unl.edu/usdaarsfacpub

Arthur, Frank H.; Throne, James E.; and Simonaitis, Richard A., "Degradation and Biological Efficacy of Chlorpyrifos-Methyl on Wheat Stored at Five Temperatures and Three Moisture Contents" (1992).

Publications from USDA-ARS / UNL Faculty. 2001.

https://digitalcommons.unl.edu/usdaarsfacpub/2001

This Article is brought to you for free and open access by the U.S. Department of Agriculture: Agricultural Research Service, Lincoln, Nebraska at DigitalCommons@University of Nebraska - Lincoln. It has been accepted for inclusion in Publications from USDA-ARS / UNL Faculty by an authorized administrator of DigitalCommons@University of Nebraska - Lincoln. 


\title{
Degradation and Biological Efficacy of Chlorpyrifos-Methyl on Wheat Stored at Five Temperatures and Three Moisture Contents
}

\author{
FRANK H. ARTHUR, JAMES E. THRONE, AND RICHARD A. SIMONAITIS
}

Stored-Product Insects Research \& Development Laboratory, USDA-ARS, P.O. Box 22909, Savannah, GA 31403

\begin{abstract}
J. Econ. Entomol. 85(5): 1994-2002 (1992)
ABSTRACT Soft red winter wheat was treated with a calculated dosage of $6 \mathrm{ppm}$ chlorpyrifos-methyl and stored at $15,20,25,30$, or $35^{\circ} \mathrm{C}$ and either $11.2,12.1$, or $13.7 \%$ moisture content (15 combinations). Measured residue deposition on the wheat was $4.39 \pm$ $0.57 \mathrm{ppm}$, a $27.2 \%$ reduction from the calculated dosage. Residue degradation was asymptotic at all combinations except $15^{\circ} \mathrm{C}$ and 11.2 and $12.1 \%$ moisture content. Residue loss during the initial months of storage increased with increases in both temperature and moisture content within temperature. Rice weevils, Sitophilus oryzae (L.), did not survive bimonthly bioassays on wheat stored at either 15 or $20^{\circ} \mathrm{C}$, but did survive on wheat stored at $20^{\circ} \mathrm{C}$ and $13.7 \%$ moisture content. Above $20^{\circ} \mathrm{C}$, survival on treated wheat increased as residues decreased, and residues became either inactivated or diluted by increased moisture content. Numbers of $F_{1}$ progeny, the percentage of insect-damaged kernels, and the amount of ground wheat flour (dockage) were positively correlated with weevil survival and negatively correlated with residue levels.
\end{abstract}

KEY WORDS Sitophilus oryzae, wheat, insecticide degradation

THE ORGANOPHOSPHATE INSECTICIDE chlorpyrifos-methyl is labeled at the rate of $6 \mathrm{ppm}$ as a protectant of wheat stored in the United States. Chlorpyrifos-methyl has been labeled since 1985 for direct application to wheat for storage, but recent surveys indicate malathion is still extensively used as a grain protectant in the southern Plains (Cuperus et al. 1990, Reed et al. 1990). However, malathion labels are being amended and post-harvest usage may be eliminated (Abramson 1991). Synergised pyrethrins and methoprene are labeled but not widely used in the field, and the loss of malathion may lead to increased applications with chlorpyrifos-methyl.

After winter wheat crops are harvested in spring or summer, wheat can be stored on-farm or in commercial storage for 3-15 mo (Halliday et al. 1992). However, the degradation rates of chlorpyrifos-methyl and other organophosphates increase as commodity temperatures and moisture contents increase (Desmarchelier \& Bengston 1979, Snelson 1987), and residue loss during the initial months of storage can be substantial. Favorable environmental conditions for organophosphate degradation during these initial

This article reports the results of research only. Mention of a proprietary product does not constitute an endorsement or a recommendation for its use by USDA. months of storage can promote rapid growth of insect pest populations during later storage.

Several published studies of chlorpyrifosmethyl degradation on wheat stored at various temperatures use only one moisture content (LaHue 1974, Desmarchelier 1978), or wheat stored at one temperature and several moisture contents (Samson et al. 1988, Samson \& Parker 1989). A single study of chlorpyrifos-methyl degradation rates on wheat stored at several temperatures and moisture contents representative of field conditions would provide valuable data for management programs and for developing new predictive models. Arthur et al. (1991) described chlorpyrifos-methyl degradation on corn stored at four temperatures and three moisture contents, and although Desmarchelier \& Bengston (1979) state that protectant degradation is independent of grain type, there are no published data verifying this assumption.

No published data relate biological efficacy to chlorpyrifos-methyl residue degradation on wheat stored at different temperatures and moisture contents. The rice weevil, Sitophilus oryzae (L.), is a primary pest of wheat and other cereals stored in temperate climates and is among those species controlled by chlorpyrifos-methyl, as indicated on the label. The four objectives of this test were: (1) to describe chlorpyrifos-methyl degradation on wheat stored at a range of tem- 
peratures and moisture contents, (2) to determine rice weevil survival on wheat treated with chlorpyrifos-methyl and stored at each temperature-moisture combination, (3) to determine residual protection at each temperature-moisture combination by establishing a threshold residue for rice weevil survival and estimating the storage date at which residues fall below threshold, and (4) to correlate residues with weevil survival and progeny production and correlate survival and progeny production with insect damage.

\section{Materials and Methods}

Chlorpyrifos-methyl degradation on wheat was determined at $15,20,25,30$, and $35^{\circ} \mathrm{C}$ (in five environmental chambers), and at three humidities controlled by aqueous solutions of $\mathrm{K}_{2} \mathrm{CO}_{3}, \mathrm{NaBr}$, and $\mathrm{NaCl}$ within each temperature (Greenspan 1977). These solutions gave approximate moisture contents of $11.4,12.4$, and $14.4 \%$, respectively, in corn (Arthur et al. 1991), but no data are available for wheat. Soft red winter wheat was obtained from a commercial facility, fumigated with phosphine, and stored at $4.4^{\circ} \mathrm{C}$. The wheat was removed from cold storage and allowed to warm under ambient conditions for several days before insecticide was applied. Spray solutions of chlorpyrifos-methyl were formulated from a $4 \mathrm{E}$ (emulsifiable concentrate, $1.82 \mathrm{~kg} / 3.75$ liter) formulation (Gustafson, Plano, TX) to yield a theoretical application of $6 \mathrm{ppm}$. The wheat was sprayed at the rate of $18.9 \mathrm{ml}$ of formulated spray per $27.27 \mathrm{~kg}$ ( 1 bushel) to correspond with the field spray rate of 18.9 liters per $27,272 \mathrm{~kg}$. Insecticide solutions were applied using a delivery system equipped with a Teejet 650033 nozzle (Spraying Systems, Wheaton, IL). Each spray treatment was replicated four times, and after each replicate bushel was treated, it was transferred three times from one cylindrical can to another to distribute the solution. A separate bushel was treated with $18.9 \mathrm{ml}$ distilled water as a control. The moisture content of the wheat after insecticide application, as determined using a Burrows DMC-700 moisture computer (Seedboro Equipment, Chicago, IL), was $12.9 \pm 0.05 \%$.

After each replicate bushel was treated, each of 75 0.48-liter jars was filled with $350 \mathrm{~g}$ wheat. Each of 60 0.48-liter jars was filled with $350 \mathrm{~g}$ wheat from the control bushel. These jars were set in each of the five temperature cabinets as follows: five jars from replicate 1 , five jars from replicate 2 , and two jars of untreated wheat were randomly placed in a plastic box containing one of the three salt solutions. Five jars from replicate 3 , five jars from replicate 4 , and two jars of untreated wheat were also randomly placed in a plastic box containing one of the three salt solutions. These boxes were then randomly assigned to the shelves in the temperature cabinet (two

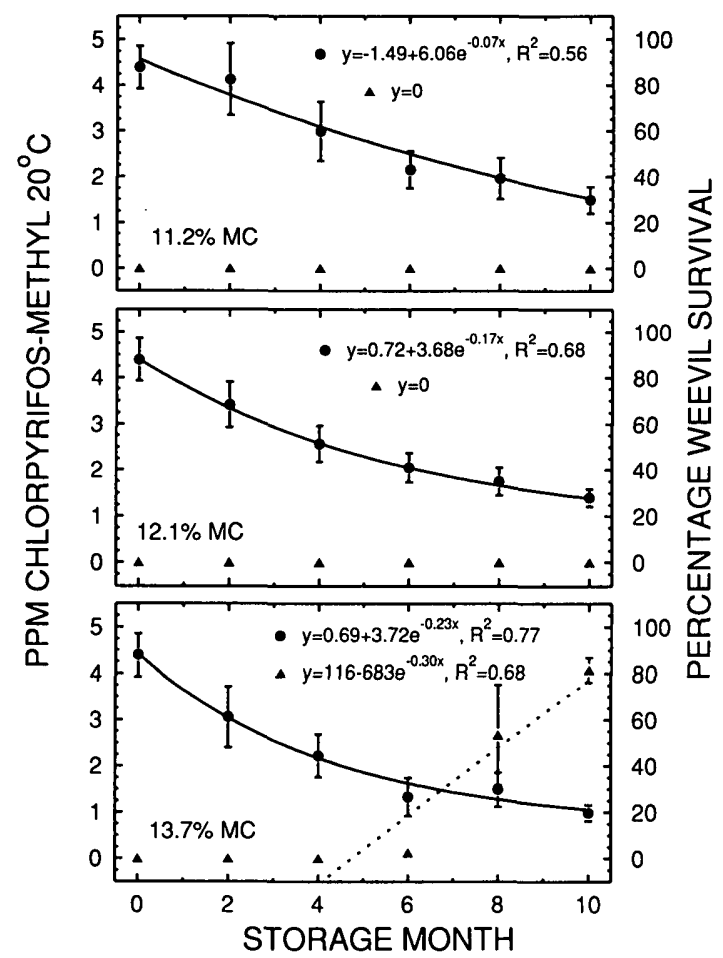

Fig. 1. Linear and asymptotic equations for chlorpyrifos-methyl degradation on wheat stored at $15^{\circ} \mathrm{C}$ and $11.2,12.1$, and $13.7 \%$ moisture contents, $y$, ppm, $x$, storage month; solid circles with error bars are means \pm SEM for residues on each sample date; survival was always 0 on each sample data (solid triangles).

boxes for each moisture content, six boxes in each cabinet).

Samples were taken after insecticide application (month 0 ) by collecting $350 \mathrm{~g}$ wheat in 0.48 liter jars from each of the four treated bushels and the untreated control and dividing the wheat lot into two 0.24-liter jars containing $175 \mathrm{~g}$ each. One jar from each treated replicate and the jar containing the untreated control were frozen at $-17.8{ }^{\circ} \mathrm{C}$ for residue analysis. Fifty adult rice weevils (1-2 wk old, sex not determined) from pesticide susceptible laboratory colonies were exposed in each of the remaining five jars, and the jars were placed in a controlled environment at $28 \pm 1{ }^{\circ} \mathrm{C}, 60 \pm 2 \% \mathrm{RH}$, and a 12:12 (L:D) photoperiod. After $5 \mathrm{~d}$, the wheat was sifted with a U.S. standard no. 10 sieve and discarded. No weevils survived on the treated wheat.

The jars in the temperature cabinets were sampled as follows. After $2,4,6,8$, and $10 \mathrm{mo}$, one jar from each treated replicate was removed from the plastic solution boxes (five temperatures, three moisture contents, four replicates; 60 total jars for each sample date). After moisture content was determined, $175 \mathrm{~g}$ of wheat were removed and placed in a 0.24 -liter jar, which was frozen at 


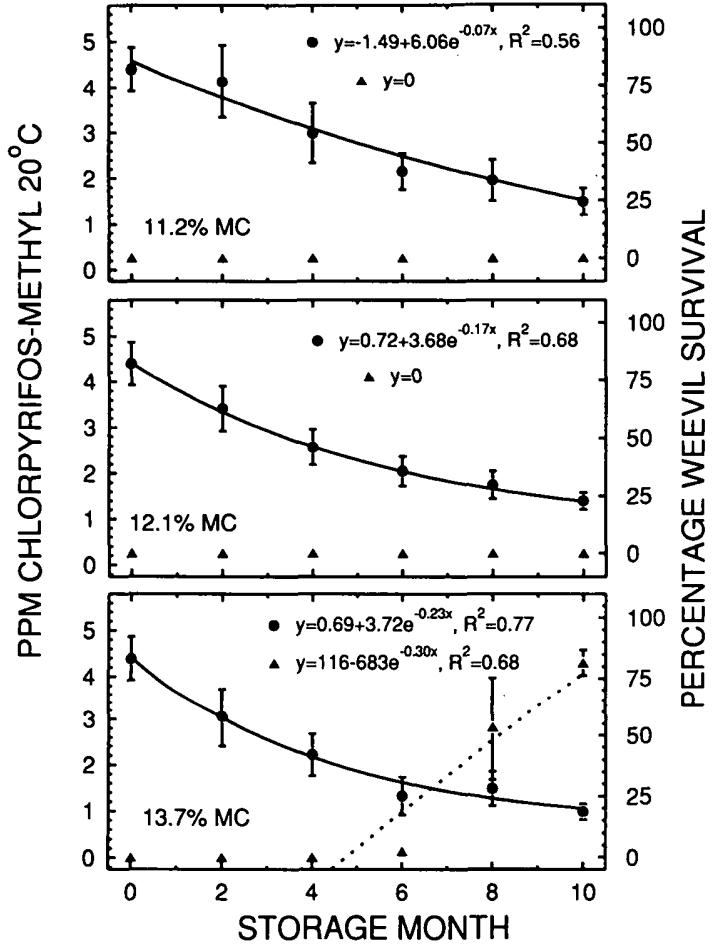

Fig. 2. Asymptotic equations (solid line) for chlorpyrifos-methyl degradation and rice weevil survival (dotted line) on wheat stored at $20^{\circ} \mathrm{C}$ and 11.2 , 12.1 , and $13.7 \%$ moisture contents, $y, \mathrm{ppm}, \mathrm{x}$, storage month; solid circles with error bars are means \pm SEM for residues on each sample date, $y$, survival, $x$, storage month; solid triangles with error bars are means \pm SEM for survival on each sample date.

$-17.8^{\circ} \mathrm{C}$ for subsequent residue analysis; the remaining $175 \mathrm{~g}$ were kept in the original jar. All 60 jars were then placed in the controlled environment. In addition, 15 jars of $175 \mathrm{~g}$ untreated wheat were included as controls ( 1 for each original combination of temperature and moisture content). Fifty susceptible rice weevils were released in each jar. After $5 \mathrm{~d}$, the wheat was sifted, the number of survivors was recorded, and live weevils were returned to the jars for further incubation. After $49 \mathrm{~d}$, the wheat was resifted and the number of live weevils and the weight of the ground flour (from insect feeding) were recorded. The wheat was poured back into the jar, and a cylinder ( $3.2 \mathrm{ml}$ diameter, $11.4 \mathrm{~cm}$ long) attached to the underside of a jar lid was used to remove a $37.7-\mathrm{ml}$ core subsample, from which 100 kernels were examined for insect damage. All treated wheat was discarded after it was sampled.

Chlorpyrifos-methyl residues were analyzed as reported by Arthur et al. (1988). Data were analyzed using the nonlinear regression procedure of the Statistical Analysis System (SAS In-

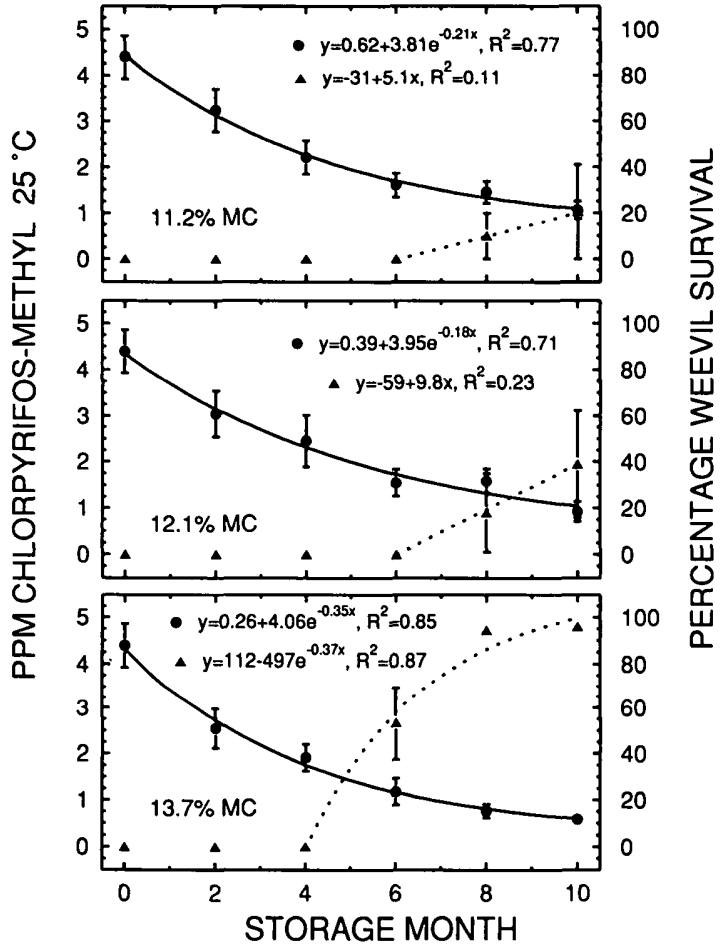

Fig. 3. Asymptotic equations (solid line) for chlorpyrifos-methyl degradation and linear and asymptotic equations for rice weevil survival (dotted line) on wheat stored at $25^{\circ} \mathrm{C}$ and $11.2,12.1$, and $13.7 \%$ moisture contents, $y, \mathrm{ppm}, \mathrm{x}$, storage month; solid circles with error bars are means \pm SEM for residues on each sample date; $y$, survival; $x$, storage month; solid triangles with error bars are means \pm SEM for survival on each sample date.

stitute 1987) to fit asymptotic equations for residue degradation at each temperature and moisture content. The regression procedure was used to fit linear regression equations when asymptotic equations could not be fit for residue degradation. The 5-d survival counts were converted to percentages, and equations were fit by using the last sample month in which survival equalled 0 as a starting point and ignoring previous 0 values. Linear equations were fit when asymptotic equations could not be fit. The survival threshold was estimated by averaging the difference between the upper residue level where survival was always 0 and the lower residue level where survival was always greater than 0 . This value was substituted in the degradation equation, and the equations were solved for this value to determine the storage month at which this threshold was exceeded. The linear correlation procedure (SAS Institute 1987) was used to correlate residues with survival and 49-d counts, survival with 49-d counts, and survival and 49-d counts with dockage weight and the percentage of insect-damaged kernels. 


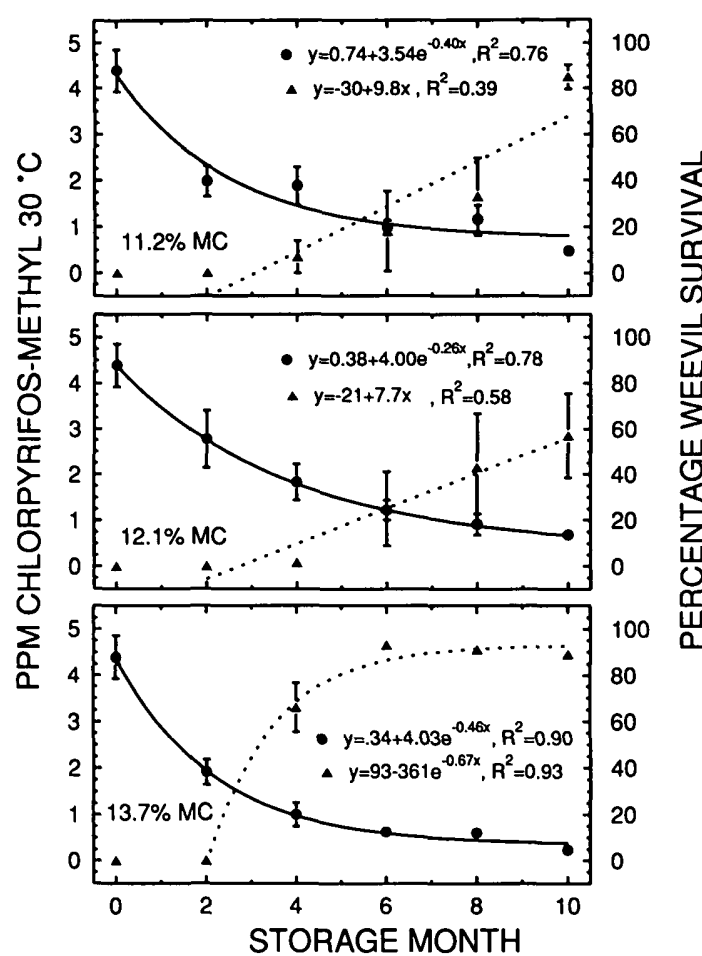

Fig. 4. Asymptotic equations (solid line) for chlorpyrifos-methyl degradation and linear and asymptotic equations for rice weevil survival (dotted line) on wheat stored at $30^{\circ} \mathrm{C}$ and $11.2,12.1$, and $13.7 \%$ moisture contents. $y, \mathrm{ppm} ; \mathrm{x}$, storage month; solid circles with error bars are means $\pm S E M$ for residues on each sample date; $y$, survival; $x$, storage month; solid triangles with error bars are means \pm SEM for survival on each sample date.

\section{Results}

From month 2 until the end of the test, actual moisture contents for wheat in the $11.0 \% \mathrm{~K}_{2} \mathrm{CO}_{3}$, $12.5 \% \mathrm{NaBr}$, and $14.5 \% \mathrm{NaCl}$ saturated salt solutions averaged $11.2 \pm 0.04,12.1 \pm 0.04$, and 13.7 $\pm 0.06 \%$ (mean $\pm \mathrm{SE}$ ), respectively. All of the treated wheat had equilibrated to these concentrations by the first sampling date. Chlorpyrifosmethyl deposition on the wheat after application was $4.39 \pm 0.47 \mathrm{ppm}$, or $27.2 \%$ less than the calculated dosage.

At $15^{\circ} \mathrm{C}$ and 11.2 and $12.1 \%$ moisture contents, the relationship between chlorpyrifos-methyl degradation and storage time was linear (Fig. 1). Degradation at $13.7 \%$ moisture content was described by a negatively asymptotic curve (Fig. 1). Residues on wheat stored at 11.2 and $12.1 \%$ moisture content did not decline between month 0 and 2 , and residue loss during this time on wheat stored at $13.7 \%$ moisture content was $14.1 \%$. Residues at the conclusion of the test $(10$ mo) were $1.79 \pm 0.28,1.78 \pm 0.35$, and $1.55 \pm$ $0.25 \mathrm{ppm}$ for each of the three moisture contents

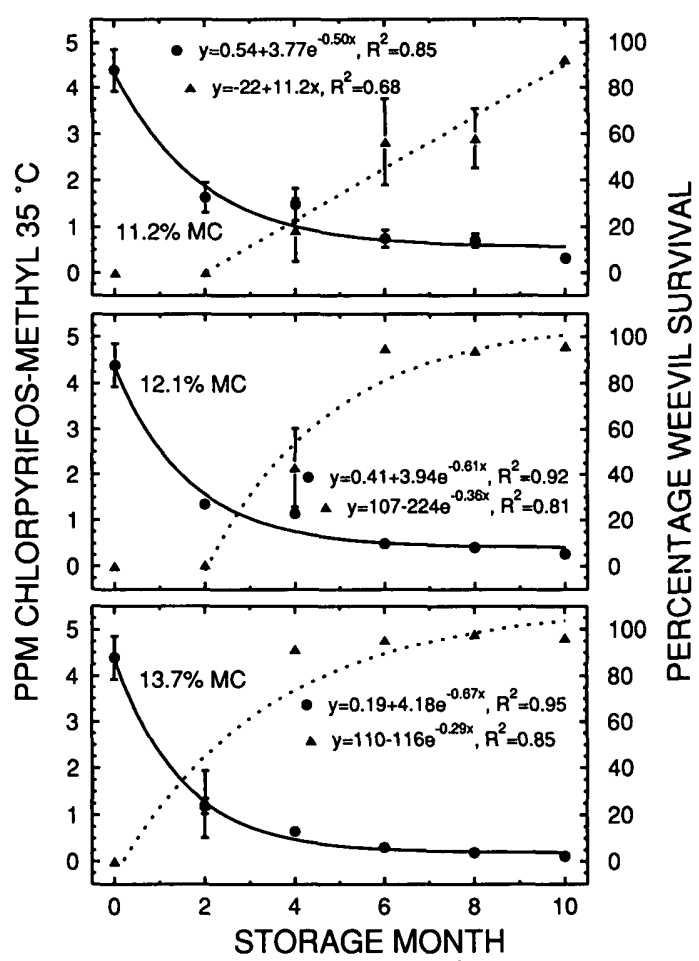

Fig. 5. Asymptotic equations (solid line) for chlorpyrifos-methyl degradation and linear and asymptotic equations for rice weevil survival (dotted line) on wheat stored at $35^{\circ} \mathrm{C}$ and $11.2,12.1$, and $13.7 \%$ moisture contents $\mathrm{y}, \mathrm{ppm} ; \mathrm{x}$, storage month; solid circles with error bars are means \pm SEM for residues on each sample date; $y$, survival; $x$, storage month; solid triangles with error bars are means \pm SEM for survival on each sample date.

in succession, and no rice weevils survived any of the bimonthly introductions on the wheat.

Asymptotic equations for residue degradation were fit to data for $20^{\circ} \mathrm{C}$, and model fitness increased as moisture content increased (Fig. 2). Residue loss between month 0 and 2 was 5.9 , 22.3 , and $25.9 \%$ for the successive moisture contents. Degradation was greatest at $13.7 \%$ moisture content, and after $10 \mathrm{mo}$, residues were $1.48 \pm 0.29,1.40 \pm 0.19$, and $0.99 \pm 0.17 \mathrm{ppm}$ chlorpyrifos-methyl. No rice weevils survived any of the bimonthly introductions on wheat stored at 11.2 and $12.1 \%$ moisture content, nor did any survive on wheat stored at $13.7 \%$ moisture content until month 8 . An asymptotic equation was fit to the data.

Residue loss between month 0 and 2 at $25^{\circ} \mathrm{C}$ was $26.4,30.8$, and $42.1 \%$ for the successive moisture contents, and after 10 mo, residues were $1.06 \pm 0.18,0.91 \pm 0.21$, and $0.57 \pm 0.09$ ppm (Fig. 3). No weevils survived on wheat stored at 11.2 and $12.1 \%$ moisture contents until month 8; linear equations were fit to these data. 
Table 1. Storage month ( $\pm 95 \% \mathrm{CI}$ ) when chlorpyrifosmethyl residues equaled 1.65 ppm; asymptotic degradations were solved for this level

\begin{tabular}{cccc}
\hline \hline \multirow{2}{*}{ Temperature, ${ }^{\circ} \mathrm{C}$} & \multicolumn{3}{c}{ \% Moisture content } \\
\cline { 2 - 4 } & 11.2 & 12.1 & 13.7 \\
\hline $15^{a}$ & - & - & - \\
20 & $10.65 \pm 3.38^{b}$ & $9.95 \pm 5.37^{b}$ & $7.20 \pm 2.54$ \\
25 & $7.54 \pm 1.98$ & $7.58 \pm 2.13$ & $5.08 \pm 1.17$ \\
30 & $4.24 \pm 1.36$ & $5.23 \pm 1.41$ & $2.90 \pm 1.02$ \\
35 & $2.96 \pm 1.02$ & $2.26 \pm 0.49$ & $1.85 \pm 0.34$ \\
\hline
\end{tabular}

${ }^{a}$ Curves not solved because survival was always 0 .

${ }^{b}$ No survival at these two moisture contents.

Weevil survival occurred after 6 mo on wheat stored at $13.7 \%$ moisture content. An asymptotic equation was fit to the data.

At $30^{\circ} \mathrm{C}$ chlorpyrifos-methyl degradation during the first 2 mo of storage was less in wheat stored at $12.1 \%$ moisture content than in wheat stored at $11.2 \%$ moisture content (Fig. 4). Residue loss during months 0 and 2 was 54.9, 36.9, and $56.7 \%$ for the successive moisture contents, and after $10 \mathrm{mo}$, residues were $0.48 \pm 0.08,0.68$ \pm 0.14 , and $0.23 \pm 0.06 \mathrm{ppm}$. Weevil survival was 0 until month 4 , and the relationship was linear at the two lower moisture contents and asymptotic at $13.7 \%$ (Fig. 4).

Chlorpyrifos-methyl degradation was greatly accelerated in wheat stored at $35^{\circ} \mathrm{C}$ (Fig. 5). Residue loss during mo 0 and 2 was $62.9,69.2$, and $72.9 \%$ for the successive moisture contents and residues after 10 mo were only $0.30 \pm 0.07,0.26$ \pm 0.02 , and $0.11 \pm 0.03 \mathrm{ppm}$. Weevil survival was 0 until month 4 on wheat stored at 11.2 and $12.1 \%$, but at month $2, \approx 22 \%$ survival occurred on wheat stored at $13.7 \%$ moisture content. The relationship was linear at $11.1 \%$ wheat moisture content and asymptotic at the two higher moisture contents.
When chlorpyrifos-methyl residues exceeded $1.90 \mathrm{ppm}$, rice weevil survival was 0 , and when residues were $<1.40 \mathrm{ppm}$, weevil survival was $>0$. There were nine residue levels between these two values, and weevils survived at four of these levels. Therefore, $1.65 \mathrm{ppm}$ was chosen as a survival threshold, the degradation equations were solved for storage month $(x)$, and $95 \%$ CIs were fit to this estimate. Residues on wheat stored at $20^{\circ} \mathrm{C}$ and $13.7 \%$ moisture content and $25^{\circ} \mathrm{C}$ and 11.2 and $12.1 \%$ moisture content were considered effective for $>7 \mathrm{mo}$ (Table 1 ). As temperature increased within each moisture content, residues fell below the threshold earlier in the storage period.

Weevil survival in untreated wheat was $96.8 \pm$ $0.35 \%$ during the test, and the number of subsequent $F_{1} s$ was $694 \pm 34.9$. Although no individual weevils survived any of the bioassays on months 6,8 , and 10 in treated wheat stored at $15^{\circ} \mathrm{C}$ and either 12.1 or $13.7 \%$ moisture content, $F_{1}$ adults were collected when the wheat was resifted after being held for $49 \mathrm{~d}$ under the new environmental conditions (Table 2). Among all five temperatures, the number of $F_{1} s$ from wheat originally stored at $11.2 \%$ moisture content ranged from $0 \pm 0.0$ to $21 \pm 10.5$, with the exception of the 10 -mo sample at $35^{\circ} \mathrm{C}$. Within each temperature except $15^{\circ} \mathrm{C}$, the number of $F_{1} \mathrm{~s}$ from wheat originally stored at $13.7 \%$ moisture content was usually at least four times the number from wheat originally stored at $12.1 \%$ moisture content. Weevil populations from wheat stored at $12.1 \%$ moisture content usually increased with each successive sample date, but after $6 \mathrm{mo}$, the number of $F_{1} s$ from wheat stored at 25,30 , and $35^{\circ} \mathrm{C}$ and $13.7 \%$ moisture content did not increase with sample date, and populations ranged from $430 \pm 66.8$ to $633 \pm 91.2$.

Table 2. Number of live $F_{1}$ adult rice weevils $(\bar{x} \pm S E)$ in $175 \mathrm{~g}$ wheat $49 \mathrm{~d}$ after the wheat was removed from storage and infested with 50 unsexed adults

\begin{tabular}{|c|c|c|c|c|c|c|}
\hline \multirow{3}{*}{$\begin{array}{c}\begin{array}{l}\text { Original } \\
\text { temp }\end{array}{ }^{\circ} \mathrm{C} \\
15\end{array}$} & \multirow{3}{*}{$\begin{array}{c}\begin{array}{c}\% \text { Moisture } \\
\text { content }\end{array} \\
11.2 \\
12.1 \\
13.7\end{array}$} & \multicolumn{5}{|c|}{ Mo wheat removed from storage } \\
\hline & & 2 & 4 & 6 & 8 & 10 \\
\hline & & $\begin{array}{l}0 \pm 0.0 \\
0 \pm 0.0 \\
0 \pm 0.0\end{array}$ & $\begin{array}{l}0 \pm 0.0 \\
0 \pm 0.0 \\
1 \pm 0.5\end{array}$ & $\begin{array}{rr}0 \pm & 0.0 \\
5 \pm & 4.7 \\
13 \pm & 9.8\end{array}$ & $\begin{array}{rr}0 \pm & 0.0 \\
16 \pm & 15.3 \\
33 \pm & 28.9\end{array}$ & $\begin{array}{rr}0 \pm & 0.0 \\
28 \pm & 23.7 \\
76 \pm & 64.8\end{array}$ \\
\hline 20 & $\begin{array}{l}11.2 \\
12.1 \\
13.7\end{array}$ & $\begin{array}{l}0 \pm 0.0 \\
1 \pm 0.9 \\
1 \pm 1.2\end{array}$ & $\begin{array}{l}0 \pm 0.0 \\
3 \pm 2.2 \\
6 \pm 1.9\end{array}$ & $\begin{array}{rr}7 \pm & 6.9 \\
20 & \pm 16.8 \\
223 & \pm 135.4\end{array}$ & $\begin{array}{rr}2 \pm & 1.4 \\
27 \pm & 23.3 \\
334 \pm & 53.4\end{array}$ & $\begin{array}{rr}11 & \pm 9.8 \\
50 & \pm 24.1 \\
771 & \pm 130.1\end{array}$ \\
\hline 25 & $\begin{array}{l}11.2 \\
12.1 \\
13.7\end{array}$ & $\begin{array}{l}7 \pm 5.2 \\
3 \pm 2.6 \\
5 \pm 2.6\end{array}$ & $\begin{array}{r}6 \pm 5.5 \\
7 \pm 5.5 \\
49 \pm 25.0\end{array}$ & $\begin{array}{r}13 \pm 10.5 \\
37 \pm 21.2 \\
476 \pm 65.0\end{array}$ & $\begin{array}{rr}8 \pm & 2.1 \\
63 & \pm 23.4 \\
584 & \pm 109.6\end{array}$ & $\begin{array}{rr}12 \pm 6.4 \\
131 \pm 39.6 \\
541 \pm 103.0\end{array}$ \\
\hline 30 & $\begin{array}{l}11.2 \\
12.1 \\
13.7\end{array}$ & $\begin{array}{r}4 \pm 1.1 \\
11 \pm 4.7 \\
26 \pm 7.3\end{array}$ & $\begin{array}{rr}0 \pm & 0.0 \\
7 \pm & \pm .6 \\
155 & \pm 32.0\end{array}$ & $\begin{array}{rr}3 \pm & 0.3 \\
84 & \pm 21.7 \\
633 \pm & 91.2\end{array}$ & $\begin{aligned} 0 & \pm 0.0 \\
62 & \pm 3.7 \\
430 & \pm 66.8\end{aligned}$ & $\begin{array}{rr}0 \pm & 0.0 \\
69 \pm & 26.3 \\
473 \pm & 95.9\end{array}$ \\
\hline 35 & $\begin{array}{l}11.2 \\
12.1 \\
13.7\end{array}$ & $\begin{array}{r}4 \pm 2.6 \\
36 \pm 7.3 \\
182 \pm 57.3\end{array}$ & $\begin{array}{r}0 \pm 0.0 \\
7 \pm 4.5 \\
307 \pm 40.7\end{array}$ & $\begin{array}{r}21 \pm 10.5 \\
77 \pm 11.8 \\
487 \pm 90.7\end{array}$ & $\begin{array}{rr}10 & \pm 0.0 \\
70 \pm & 17.7 \\
483 \pm & 40.0\end{array}$ & $\begin{array}{rr}41 \pm & 8.5 \\
113 \pm & 50.8 \\
386 \pm & 65.3\end{array}$ \\
\hline
\end{tabular}


Table 3. Percentage of insect-damaged kernels $(\bar{x} \pm S E M)$ in $175 \mathrm{~g}$ wheat $49 \mathrm{~d}$ after the wheat was removed from storage and infested at the rate of 50 unsexed adults per $175 \mathrm{~g}$

\begin{tabular}{ccrrrrr}
\hline \hline $\begin{array}{c}\text { Original } \\
\text { temp }{ }^{\circ} \mathrm{C}\end{array}$ & $\begin{array}{c}\text { \% Moisture } \\
\text { content }\end{array}$ & \multicolumn{1}{c}{2} & \multicolumn{1}{c}{ Mo wheat removed from storage } \\
\cline { 2 - 6 } 15 & 11.2 & $0.7 \pm 0.4$ & $0.0 \pm 0.0$ & $0.2 \pm 0.2$ & $0.2 \pm 0.2$ & \multicolumn{1}{c}{6} \\
\hline & 12.1 & $0.2 \pm 0.2$ & $0.5 \pm 0.3$ & $1.3 \pm 0.9$ & $1.5 \pm 1.2$ & $0.5 \pm 0.3$ \\
& 13.7 & $0.5 \pm 0.3$ & $1.0 \pm 4.0$ & $6.3 \pm 0.9$ & $6.8 \pm 2.5$ & $6.8 \pm 3.0$ \\
20 & 11.2 & $0.2 \pm 0.2$ & $0.8 \pm 0.2$ & $1.7 \pm 1.4$ & $1.0 \pm 1.7$ & $1.7 \pm 1.1$ \\
& 12.1 & $1.0 \pm 0.7$ & $1.5 \pm 0.3$ & $3.3 \pm 1.6$ & $4.5 \pm 2.8$ & $7.3 \pm 2.0$ \\
& 13.7 & $0.5 \pm 0.3$ & $2.2 \pm 0.5$ & $13.5 \pm 7.1$ & $17.5 \pm 2.6$ & $45.7 \pm 7.4$ \\
25 & 11.2 & $1.5 \pm 0.9$ & $2.5 \pm 0.9$ & $3.7 \pm 1.5$ & $4.5 \pm 2.5$ & $4.7 \pm 1.9$ \\
& 12.1 & $2.7 \pm 0.9$ & $3.7 \pm 1.4$ & $6.2 \pm 2.9$ & $8.7 \pm 2.5$ & $13.2 \pm 4.1$ \\
& 13.7 & $2.7 \pm 0.7$ & $5.2 \pm 1.3$ & $20.0 \pm 3.8$ & $35.2 \pm 5.5$ & $45.0 \pm 3.2$ \\
30 & 11.2 & $2.0 \pm 0.4$ & $1.2 \pm 0.6$ & $4.0 \pm 0.7$ & $4.0 \pm 2.2$ & $7.2 \pm 1.7$ \\
& 12.1 & $4.2 \pm 1.1$ & $5.5 \pm 0.9$ & $8.8 \pm 1.6$ & $12.0 \pm 1.6$ & $14.0 \pm 2.5$ \\
& 13.7 & $7.8 \pm 0.8$ & $13.0 \pm 2.3$ & $33.0 \pm 6.0$ & $30.5 \pm 5.0$ & $39.0 \pm 6.9$ \\
35 & 11.2 & $2.8 \pm 0.5$ & $3.0 \pm 0.4$ & $8.5 \pm 1.3$ & $9.5 \pm 1.0$ & $10.7 \pm 0.7$ \\
& 12.1 & $7.7 \pm 1.0$ & $8.7 \pm 1.2$ & $13.7 \pm 0.7$ & $14.0 \pm 1.2$ & $14.7 \pm 2.6$ \\
& 13.7 & $14.0 \pm 1.8$ & $20.2 \pm 1.2$ & $29.5 \pm 4.4$ & $31.7 \pm 2.7$ & $29.2 \pm 4.3$ \\
\hline
\end{tabular}

Insect-damaged kernels in untreated wheat 49 $\mathrm{d}$ after initial infestation with rice weevils averaged $46.7 \pm 1.61 \%$ during the test. With each successive bioassay of treated wheat sifted $49 \mathrm{~d}$ after initial infestation, the percentage of insectdamaged kernels from wheat originally stored at 11.2 and $12.1 \%$ moisture content generally increased as temperature increased (Table 3 ). The percentage of damaged kernels in the 8- and 10-mo bioassays of wheat stored at $13.7 \%$ moisture content did not increase between 25 and $35^{\circ} \mathrm{C}$.

The amount of ground flour in untreated wheat $49 \mathrm{~d}$ after initial infestation averaged $2.5 \pm 0.14 \mathrm{~g}$ during the test. Dockage from treated wheat stored at 11.2 and $12.2 \%$ moisture contents ranged from $0.0 \pm 0.00$ to $0.6 \pm 0.14 \mathrm{~g}$ during the test. From months 6 to 10 , dockage in wheat originally stored at $13.7 \%$ moisture content was approximately four times greater than dockage in wheat stored at either 11.2 or $12.1 \%$ moisture content (Table 4). Dockage in wheat from the 8 and 10-mo bioassays of wheat stored at $13.7 \%$ moisture content was similar at 25,30 , and $35^{\circ} \mathrm{C}$.

When rice weevil survival after introduction on the treated wheat was greater than 0 , chlorpyrifos-methyl residues were usually negatively correlated with both survival and subsequent $F_{1}$ progeny (Table 5). Residues were not correlated with weevil survival on wheat stored at $25^{\circ} \mathrm{C}$, and 11.2 and $12.1 \%$ moisture content, nor were they correlated with $F_{1}$ progeny from wheat originally stored at $30^{\circ} \mathrm{C}$ and $11.2 \%$ moisture content.

\section{Discussion}

Chlorpyrifos-methyl residue deposition on wheat after application was approximately $27.2 \%$ less than the calculated dose. A certain percent-

Table 4. Ground flour (in grams, $\bar{x} \pm$ SE) in $175 \mathrm{~g}$ wheat $49 \mathrm{~d}$ after wheat was removed from storage and infested at the rate of 50 unsexed adults per $175 \mathrm{~g}$

\begin{tabular}{ccccccc}
\hline \hline $\begin{array}{c}\text { Original } \\
\text { temp }{ }^{\circ} \mathrm{C}\end{array}$ & $\begin{array}{c}\text { \% Moisture } \\
\text { content }\end{array}$ & 2 & 4 & 6 & 8 & 10 \\
\cline { 2 - 7 } & 11.2 & $0.0 \pm 0.00$ & $0.0 \pm 0.00$ & $0.0 \pm 0.00$ & $0.0 \pm 0.00$ & $0.0 \pm 0.00$ \\
& 12.1 & $0.0 \pm 0.00$ & $0.0 \pm 0.00$ & $0.1 \pm 0.50$ & $0.1 \pm 0.50$ & $0.1 \pm 0.05$ \\
& 13.7 & $0.0 \pm 0.00$ & $0.0 \pm 0.00$ & $0.1 \pm 0.02$ & $0.2 \pm 0.07$ & $0.3 \pm 0.18$ \\
20 & 11.2 & $0.0 \pm 0.00$ & $0.0 \pm 0.00$ & $0.0 \pm 0.00$ & $0.0 \pm 0.00$ & $0.0 \pm 0.00$ \\
& 12.1 & $0.0 \pm 0.00$ & $0.0 \pm 0.00$ & $0.1 \pm 0.03$ & $0.1 \pm 0.03$ & $0.1 \pm 0.03$ \\
& 13.7 & $0.0 \pm 0.00$ & $0.1 \pm 0.00$ & $1.0 \pm 0.41$ & $0.8 \pm 0.19$ & $2.6 \pm 0.64$ \\
25 & 11.2 & $0.0 \pm 0.00$ & $0.0 \pm 0.00$ & $0.1 \pm 0.00$ & $0.1 \pm 0.03$ & $0.3 \pm 0.23$ \\
& 12.1 & $0.0 \pm 0.00$ & $0.0 \pm 0.00$ & $0.2 \pm 0.03$ & $0.2 \pm 0.03$ & $0.3 \pm 0.10$ \\
& 13.7 & $0.1 \pm 0.03$ & $0.1 \pm 0.03$ & $1.1 \pm 0.30$ & $1.9 \pm 0.37$ & $2.1 \pm 0.41$ \\
30 & 11.2 & $0.0 \pm 0.00$ & $0.0 \pm 0.00$ & $0.1 \pm 0.00$ & $0.1 \pm 0.00$ & $0.2 \pm 0.03$ \\
& 12.1 & $0.0 \pm 0.06$ & $0.16 \pm 0.06$ & $0.2 \pm 0.05$ & $0.4 \pm 0.06$ & $0.3 \pm 0.05$ \\
& 13.7 & $0.1 \pm 0.00$ & $0.4 \pm 0.08$ & $2.0 \pm 0.33$ & $1.6 \pm 0.20$ & $2.0 \pm 0.58$ \\
35 & 11.2 & $0.0 \pm 0.00$ & $0.1 \pm 0.02$ & $0.1 \pm 0.03$ & $0.2 \pm 0.03$ & $0.3 \pm 0.03$ \\
& 12.1 & $0.1 \pm 0.00$ & $0.1 \pm 0.02$ & $0.4 \pm 0.05$ & $0.5 \pm 0.06$ & $0.6 \pm 0.14$ \\
& 13.7 & $0.5 \pm 0.15$ & $1.0 \pm 0.16$ & $1.6 \pm 0.32$ & $1.8 \pm 0.21$ & $1.4 \pm 0.19$ \\
\hline
\end{tabular}


Table 5. Correlation coefficients and probabilities for residue versus survival, residue versus 49-d counts, survival versus 49-d counts, and survival at 49-d counts versus percentage of insect-damaged kernels and ground flour (g) for each wheat moisture content within each temperature

\begin{tabular}{|c|c|c|c|c|c|c|}
\hline \multirow{3}{*}{ Parameter } & \multicolumn{6}{|c|}{$\%$ Moisture content } \\
\hline & \multicolumn{2}{|c|}{11.2} & \multicolumn{2}{|c|}{12.1} & \multicolumn{2}{|c|}{13.7} \\
\hline & Survival & Day 49 & Survival & Day 49 & Survival & Day 49 \\
\hline & \multicolumn{6}{|c|}{$15^{\circ} \mathrm{C}$} \\
\hline \multirow[t]{2}{*}{ Residue } & 0 & 0 & 0 & -0.49 & 0 & -0.49 \\
\hline & 0 & 0 & 0 & 0.0291 & 0 & 0.0387 \\
\hline Survival & - & 0 & - & 0 & - & 0 \\
\hline \multirow{2}{*}{ Damaged kernels } & 0 & 0 & 0 & 0.95 & 0 & 0.82 \\
\hline & 0 & 0 & 0 & $0.0001^{*}$ & 0 & $0.0001^{*}$ \\
\hline \multirow{3}{*}{ Ground flour } & 0 & 0 & 0 & 0.96 & 0 & 0.97 \\
\hline & 0 & 0 & 0 & $0.0001^{*}$ & 0 & $0.0001^{*}$ \\
\hline & \multicolumn{6}{|c|}{$20^{\circ} \mathrm{C}$} \\
\hline \multirow[t]{2}{*}{ Residue } & 0 & -0.45 & 0 & -0.68 & -0.56 & -0.65 \\
\hline & 0 & 0.0420 & 0 & 0.0010 & 0.0129 & 0.0026 \\
\hline \multirow[t]{2}{*}{ Survival } & - & 0 & - & 0 & - & 0.82 \\
\hline & - & 0 & - & 0 & - & $0.0001^{*}$ \\
\hline \multirow{2}{*}{ Damaged kernels } & 0 & 0.90 & 0 & 0.96 & 0.79 & 0.79 \\
\hline & 0 & $0.0001^{*}$ & 0 & $0.0001^{*}$ & $0.0001^{*}$ & $0.0001 *$ \\
\hline \multirow{3}{*}{ Ground flour } & 0 & 0.97 & 0 & 0.78 & 0.70 & 0.70 \\
\hline & 0 & $0.0001^{*}$ & 0 & $0.0001^{*}$ & $0.0006^{*}$ & $0.0006^{*}$ \\
\hline & \multicolumn{6}{|c|}{$25^{\circ} \mathrm{C}$} \\
\hline \multirow[t]{2}{*}{ Residue } & -0.44 & 0.57 & -0.41 & -0.67 & -0.82 & -0.81 \\
\hline & 0.0545 & 0.0093 & 0.0741 & 0.0014 & $0.0001^{*}$ & $0.0001^{*}$ \\
\hline \multirow[t]{2}{*}{ Survival } & - & 0.14 & - & 0.90 & - & 0.89 \\
\hline & - & 0.5596 & - & $0.0001^{*}$ & - & $0.0001^{*}$ \\
\hline \multirow[t]{2}{*}{ Damaged kernels } & 0.72 & 0.67 & 0.82 & 0.94 & 0.94 & 0.91 \\
\hline & $0.0001^{*}$ & 0.0011 & $0.0001^{*}$ & $0.0001^{*}$ & $0.0001^{*}$ & $0.0001^{*}$ \\
\hline \multirow[t]{3}{*}{ Ground flour } & 0.02 & 0.25 & 0.80 & 0.93 & 0.89 & 0.96 \\
\hline & 0.9367 & 0.2710 & $0.0001^{*}$ & $0.000 \mathrm{I}^{*}$ & $0.0001^{*}$ & $0.0001^{*}$ \\
\hline & \multicolumn{6}{|c|}{$30^{\circ} \mathrm{C}$} \\
\hline \multirow[t]{2}{*}{ Residue } & -0.57 & -0.24 & -0.63 & -0.67 & -0.81 & -0.68 \\
\hline & 0.0086 & 0.3046 & 0.0028 & 0.0013 & $0.0001^{*}$ & 0.0010 \\
\hline \multirow[t]{2}{*}{ Survival } & - & 0.64 & - & 0.69 & - & 0.78 \\
\hline & - & 0.0021 & - & 0.0007 & - & $0.0001^{*}$ \\
\hline Damaged kernels & 0.79 & 0.80 & 0.75 & 0.66 & 0.71 & 0.90 \\
\hline & $0.0001^{*}$ & $0.0001^{*}$ & $0.0001^{*}$ & 0.0014 & $0.0004^{*}$ & $0.0001^{*}$ \\
\hline Ground flour & 0.74 & 0.76 & 0.63 & 0.66 & 0.70 & 0.93 \\
\hline & 0.0002 & $0.0001^{*}$ & 0.0026 & 0.0014 & $0.0006^{*}$ & $0.0001^{*}$ \\
\hline & & & & & & \\
\hline Residue & -0.86 & -0.68 & -0.89 & -0.69 & -0.89 & -0.77 \\
\hline & 0.0001 & 0.0010 & $0.0001^{*}$ & 0.0007 & $0.0001^{*}$ & $0.0001^{*}$ \\
\hline Survival & - & 0.74 & - & 0.65 & 一 & 0.72 \\
\hline & - & $0.0002^{*}$ & 一 & 0.0019 & - & $0.0003^{*}$ \\
\hline Damaged kernels & 0.86 & 0.76 & 0.73 & 0.93 & 0.67 & 0.76 \\
\hline & $0.0001^{*}$ & $0.0001^{*}$ & $0.0002^{*}$ & $0.0001^{*}$ & 0.0012 & $0.0001^{*}$ \\
\hline Ground flour & 0.84 & 0.72 & 0.68 & 0.95 & 0.70 & 0.75 \\
\hline & $0.0001^{*}$ & $0.0003^{*}$ & 0.0010 & $0.0001^{*}$ & $0.0006^{*}$ & $0.0001^{*}$ \\
\hline
\end{tabular}

0 , No survival on these dates; ${ }^{*}$, probabilities are significant at the 0.05 tablewise error level $(\alpha / \mathrm{k}=0.0006)$.

age of residue loss usually occurs when insecticide protectants are applied to raw agricultural commodities in either laboratory studies (Arthur et al. 1991) or field trials (Bengston et al. 1983a,b, Thomas et al. 1987). Ignoring the disparity between the calculated dose and actual deposition may exaggerate apparent residue degradation between the time of application and when the first samples are taken for residue analysis. As an example from our test using the actual deposition of $4.39 \mathrm{ppm}$ chorpyrifos-methyl, residue degradation for wheat stored at $35^{\circ} \mathrm{C}$ and $13.7 \%$ moisture content was $72.9 \%$ between 0 and 2 mo, but based on the calculated dose of $6.00 \mathrm{ppm}$, degradation increased to $80.2 \%$.

Desmarchelier \& Bengston (1979) reported a half-life for chlorpyrifos-methyl on wheat stored at $30^{\circ} \mathrm{C}$ and $50 \% \mathrm{RH}(\approx 11.9 \%$ moisture content) of $19 \mathrm{wk}$. Based on actual deposition after application of $4.39 \mathrm{ppm}$, the half-lives of chlorpyrifosmethyl on wheat stored at $30^{\circ} \mathrm{C}$ and $11.2,12.1$, and $13.7 \%$ moisture contents in our test were 8.9 , 12.1 , and $6.7 \mathrm{wk}$, respectively. Also, chlorpyrifosmethyl degradation rates appear to be different on corn and wheat. Half-lives for chlorpyrifosmethyl degradation on corn stored at $30^{\circ} \mathrm{C}$ and 
$11.4,12.4$, and $14.4 \%$ moisture content were 6.1 , 5.4 , and $3.8 \mathrm{wk}$, respectively (Arthur et al. 1991), which may indicate that specific degradation models may need to be developed for each protectant used for a particular stored commodity.

The rapid degradation of chlorpyifos-methyl on wheat stored at high temperatures and moisture contents affects current pest management programs for stored wheat, especially for regions with warm climates. In Oklahoma, winter wheat is harvested in June, and storage temperatures can exceed $35^{\circ} \mathrm{C}$ during the summer months $(\mathrm{Cu}-$ perus et al. 1986). These high summer temperatures may limit insect pest populations because they are above the developmental threshold for most species (Howe 1965). If chlorpyrifosmethyl is applied as a protectant, extensive degradation during the summer will occur, and as temperatures cool in the fall and conditions become more favorable for insect development, residue levels may not be sufficient to prevent insect infestation. In our test, chlorpyrifosmethyl residues on wheat stored at $35^{\circ} \mathrm{C}$ decreased from 1.19 to $0.64 \mathrm{ppm}$ between 2 and 4 mo, and rice weevil survival increased from 24 to $91 \%$. In the north-central states where winter wheat is harvested in late summer and storage temperatures are lower than those in the southern plains, applications of chlorpyrifos-methyl may be necessary to protect wheat from insect damage during the summer months.

Our study also demonstrates the effects of increased grain moisture content on both chlorpyrifos-methyl residue degradation and protectant efficacy. The increased moisture content at each of our storage temperatures may have caused a dilution effect and accelerated residue degradation. Several previous studies have shown that the efficacy of organophosphate protectants decreases as grain moisture content increases (Samson et al. 1987, 1988). Moisture content also affects insect population development. The severity of insect infestations in stored wheat usually increases as moisture content increases, although some pest species such as the lesser grain borer, Rhyzopertha dominica (F.), can be found in wheat with a low moisture content (Storey et al. 1983, Cuperus et al. 1986). In our test, few rice weevil progeny developed in wheat that had been stored at $11.2 \%$ moisture content.

Progeny production, damaged kernel estimates, and the weight of ground flour were determined after the jars containing the treated wheat were removed from their respective temperature and moisture content combinations and held under uniform conditions for $49 \mathrm{~d}$. Two of the temperatures in our study $\left(15\right.$ and $\left.20^{\circ} \mathrm{C}\right)$ were below the lower developmental threshold for Sitophilus spp. (Howe 1965). It was necessary to hold the wheat at the same conditions after insects were introduced so that differences in either progeny production or insect damage could be related to the amount of chlorpyrifosmethyl residues on the wheat. With few exceptions, the residue levels at the time of insect introduction were correlated with subsequent measurements, which confirmed results from the earlier chlorpyrifos-methyl degradation study with corn (Arthur et al. 1991).

If malathion is removed from the post-harvest market, chlorpyrifos-methy applications may increase because it is the only other chemical that can be economically applied as a protectant. Because organophosphates such as chlorpyrifosmethyl degrade rapidly at high temperatures and high moisture contents, they may not be useful protectants for wheat stored in hot humid climates unless aeration systems can be used to lower grain temperatures during the summer. Our studies show that chlorpyrifos-methyl degradation rates greatly exceed those previously reported for small grains. Cooling grain and reducing the moisture content would slow the degradation of chlorpyrifos-methyl during the summer but may also create more favorable conditions for insect infestation.

\section{Acknowledgment}

The authors thank J. E. O'Bryan, E. Z. Cooper, Jr., and M. Cooper for their excellent technical assistance. Gustafson, Inc., provided the chlorpyrifos-methyl used in this study.

\section{References Cited}

Abramson, A. S. 1991. Malathion; deletion of certain uses and directions for use. Fed. Reg. 56: 11419-11420.

Arthur, F. H., L. M. Redlinger \& R. A. Simonaitis. 1988. Chlorpyrifos-methyl as a protectant of farmers stock peanuts. Peanut Sci. 15: 15-18.

Arthur, F. H., J. E. Throne \& R. A. Simonaitis. 1992. Chlorpyrifos-methyl degradation and biological efficacy toward maize weevils (Coleoptera: Curculionidae) on corn stored at four temperatures and three moisture contents. J. Econ. Entomol.

Bengston, M., R.A.H. Davies, J. M. Desmarchelier, R. Henning, W. Murray, B. W. Simpson, J. T. Snelson, R. Sticka \& B. E. Wallbank. 1983a. Organophosphorothioates and synergised synthetic pyrethroids as grain protectants on bulk wheat. Pestic. Sci. 14: $373-384$

Bengston, M., L. M. Cooper, R.A.H. Davies, J. M Desmarchelier, R. H. Hart \& M. P. Phillips. 1983b. Grain protectants for the control of malathionresistant insects in stored sorghum. Pestic. Sci. 14: 385-398.

Cuperus, G. W., C. K. Prickett, P. D. Bloome \& J. T. Pitts. 1986. Insect populations in aerated and unaerated stored wheat in Oklahoma. J. Kans. Entomol. Soc. 59: 620-627.

Cuperus, G. W., R. T. Noyes, W. S. Fargo, B. L. Clary, D. C. Arnold \& K. Anderson. 1990. Management practices in a high-risk stored-wheat system in Oklahoma. Am. Entomol. 36: 129-134. 
Desmarchelier, J. M. 1978. Mathematical examination of availability to insects of aged insecticide deposits on wheat. J. Stored Prod. Res. 14: 213-222.

Desmarchelier, J. M. \& M. Bengston. 1979. The residual behaviour of chemicals on stored grain, pp. 138-151. In Proceedings 2nd International Working Conference on Stored-Product Entomology, Ibadan, Nigeria.

Greenspan, L. 1977. Humidity fixed points of binary saturated aqueous solutions. J. Res. Natl. Bur. Stand. (U.S.) 81A: 89-96.

Halliday, W. R., F. H. Arthur \& R. A. Simonaitis. 1992. Tralomethrin as a long-term protectant of stored corn and wheat. J. Agric. Entomol. (In Press)

Howe, R. W. 1965. A summary of estimates of optimal and minimal conditions for population increase of some stored-products insects. J. Stored Prod. Res. 1: 177-184.

LaHue, D. W. 1974. Pesticide residues of potential protectants of grain, pp. 635-638. In Proceedings. 1st International Working Conference Stored-Product Entomology, Savannah, GA.

Reed, C., K. Anderson, J. Brockschmidt, V. Wright \& J. Pedersen. 1990. Cost and effectiveness of chemical insect control measures in farm-stored Kansas wheat. J. Kans. Entomol. Soc. 63: 351-360.
Samson, P. R. \& R. J. Parker. 1989. Relative potency of grain protectants on maize, paddy rice, and wheat. J. Stored Prod. Res. 25: 31-38.

Samson, P. R., M. Bengston, R. J. Parker \& J. A. Keating. 1987. The effect of grain moisture on the biological activity of fenitrothion residues on maize in storage. Pestic. Sci. 19: 135-144.

Samson, P. R., R. J. Parker \& A. L. Jones. 1988. Comparative effect of grain moisture on the biological activity of protectants on stored corn. J. Econ. Entomol. 81: 949-954.

SAS Institute. 1987. SAS/STAT guide for personal computers, version 6 ed. SAS Institute, Cary, NC.

Snelson, J. T. 1987. Grain protectants. Australian Center for International Research Monograph 3.

Storey, C. L., D. B. Sauer, \& D. Walker. 1983 . Insect populations in wheat, corn, and oats stored on the farm. J. Econ. Entomol. 76: 1323-1330.

Thomas, K. P., D. B. Pinniger \& D. R. Wilkin. 1987. An assessment of chlorpyrifos-methyl, etrimfos, fenitrothion and pirimiphos-methyl as grain protectants. Pestic. Sci. 21: 57-72.

Received for publication 30 December 1991; accepted 20 April 1992. 